\title{
'An Enemy of the Rabbit': The Social Context of Acclimatisation of an Immigrant Killer
}

\author{
PHILIPPA K. WELLS
}

Department of Law, Economics, Accounting and Finance

Auckland University of Technology

PB 92006, Auckland, New Zealand

Email:pip.wells@aut.ac.nz

\section{ABSTRACT}

Along with useful and perhaps at times desirable introductions, the history of acclimatisation in New Zealand is riddled with examples of what have turned out to be catastrophic importations. Although some importations can be identified as driven by pragmatic reasons and justification, they can also in a philosophical sense be categorised as aspects of a 'Britain of the South'. The importation providing the focus of this paper is that of members of the family Mustelidae, specifically weasels, ferrets and stoats. These animals were introduced during the last twenty years of the nineteenth century to predate on rabbits, an introduced pest that in turn threatened the viability of the pastoral farming industry. The paper maps the historical context, the debate and the epilogue to the New Zealand decision to import an 'immigrant killer', not of rabbits but of iconic ground-nesting birds.

\section{KEYWORDS}

Acclimatisation, New Zealand, mustelids, rabbits, avifauna

\section{INTRODUCTION}

There is little doubt that Victorian Britons were enthusiastic practitioners of the art of acclimatisation in colonised lands. New Zealand was one of those lands colonised not only by British immigrants but also by a veritable army of plants, birds, fish, insects, and mammals. Although some of those introductions have proved benevolent and at times beneficial, there have also been those for which we in the present can find few or no redeeming features, such as gorse, broom and the Australian brush-tailed possum. However, in judging those dedicated individuals, Acclimatisation Societies and Governments who were directly or 
indirectly responsible for introductions now considered undesirable, it is important to appreciate the historical context in which such introductions were made. Frequently it would not have occurred to advocates that there might be serious negative consequences for native flora and fauna. After all, the new species did not threaten the existence of target species at their point of origin and there was little or no evidence that might suggest that things would be different in New Zealand. Even where there were warnings of negative impacts, advocates were prepared to accept that (perhaps regrettable) possibility in the interests of the greater good achieved thereby.

The history of the family Mustelidae (mustelids, specifically stoats, weasels and ferrets) in New Zealand, serves as a salutary tale in this respect. Their introduction as predators on the rabbit population has been described by King as 'a simple matter of survival ... farmers were struggling for their lives". Nevertheless, the history is arguably unusual for the period in that it was by no means uncontroversial either at the outset or by the conclusion. In addition, it is significant in signalling shifts in a broader discourse of acclimatisation as a means of effecting change.

By way of justifying this claim, this paper is organised as follows. First, it briefly traces the historical and philosophical background against which these predators were identified as 'a simple matter of survival'. Secondly, it plots and contextualises the political debate that finally led to their sanction and support. Thirdly, an all-important epilogue to the story traces and rationalises shifts in the political status of mustelids in New Zealand between 1888 and 1903. Finally, this history is placed in its wider context of acclimatisation as a historicallyspecific manifestation of a discourse of change.

\section{HISTORICAL BACKGROUND}

Mid-nineteenth-century New Zealand was not new to acclimatised species. The Maori, on their arrival in previous centuries, had brought with them such species as the gourd (hue), sweet potato (kumara), dog (kuri) and rat (kiore). European species made their first appearance with Captain Cook's visit in 1773, when he landed the pig that came to be known as the Captain Cooker in Ship Cove in the Bay of Islands, and planted cabbages on Long Island. In the fifty years following the onset of widespread British settlement in 1840, over 180 species of exotic fauna and a large range of exotic flora were to arrive in the colony, Many of these new-species introductions were neither accidental nor incidental but were in large part a reflection of a popular and official conceptualisation of the colony as the 'Britain of the South'. Two distinct but overlapping meanings can be associated with this term, both of which were instrumental in shaping contemporary acclimatisation practice. 


\section{BRITAIN OF THE SOUTH AND ACCLIMATISATION}

First, New Zealand offered a romantically- envisaged, even Utopian, 'Britain of the South'. Although R. Grove identifies the powerful symbolism of the tropics (garden and island) as offering those seeking escape from the decadence and corruption of Europe - 'a possibility of redemption, a realism in which paradise might be recreated or realised on earth, thereby implying a structure for a moral world $^{\prime 2}$ - such symbolism can equally, or perhaps even more validly, ${ }^{3}$ be located in temperate locations such as New Zealand. Settlers, who through duty, necessity or desire were compelled to leave a land corrupt, urbanised, overcrowded and polluted, had the 'British plough' to convert the New Zealand 'desert' ${ }^{\text {' }}$ into 'its original garden-like condition'; $;$ and the things of 'home' to fill it - including game birds and songsters (for example, pheasants, quail, larks and thrush), shade trees (oak and elm) and small animals (including rabbits and hares).

However, a distinctly pragmatic undertone can often be detected to such romantically-inspired acclimatisation: rabbits and hares would be a source of meat and skins; goats would be useful for clearing scrub; and shade trees would provide shelter and timber. Even 'fellow passenger', when waxing lyrical over the delightful habits and appeal of small birds, also drew specific attention to their usefulness: 'the value of [thrush and starling] to the agriculturalist cannot be overstated'?

A second meaning frequently attributed to the 'Britain of the South' is that of economic pragmatism, echoed in moves by Britain to pursue colonisation as a means of keeping New Zealand's putative resources out of the hands of France, and in contemporary writings, speeches and attitudes. ${ }^{8}$ In the immediate case of acclimatisation, P. Star argues that utility served as an important impetus, citing the Otago Acclimatization Society in support: "no country requires ... acclimatization to add to its resources more than New Zealand. ' The country had no large protein sources (being populated mainly by small birds and carrying no indigenous land mammals), only a small range of edible root vegetables and virtually no fruit. In accordance with such a purpose, early examples of introductions include sheep, poultry, cattle, pigs, various fodder and vegetable plants, bumble (or humble) bees (to fertilise red clover) and birds such as sparrows to 'kill pests (caterpillars) for farmers'. ${ }^{10}$

However, it can be argued that such pragmatism had a romantic aspect. The allotment scheme devised by the New Zealand Company in the case of the Wellington settlement - one urban to 100 rural acres - and the celebration of 'the soil-based family as the fundamental foundation of the social order " were to help shape an enduring truth of rural virtue. 'Numerous politicians' speeches, newspaper editorials and even doggerel reiterated the view of British critics of industrialisation that the transition from a rural to an urban society constituted some kind of fall'. ${ }^{12}$ New Zealand's destiny as the 'Britain of the South' therefore lay in agriculture, "with predominantly European people growing European crops 
and raising European sheep and cattle on European grass,,${ }^{13}$ a destiny requiring acclimatisation of those species.

Regardless of underlying motivation for particular instances of acclimatisation, New Zealand practitioners in the nineteenth century looked to the local scientific community for support and advice in its realisation,,${ }^{14}$ just as they did for other changes to the landscape. In justifying such assistance, scientists could look to a particular theoretical construct - the Displacement Theory or displacement.

\section{JUSTIFICATION - DISPLACEMENT}

Briefly, this theory - an extension of the Darwinian concept of 'survival of the fittest' - has been described as a 'nineteenth century blind alley"15 that nevertheless had influential supporters, including contemporary scientists and writers, ${ }^{16}$ who referred to its concepts in explaining and predicting the decline of species in New Zealand after the commencement of colonisation. As Charles Darwin explained: 'if all the animals and plants of Great Britain were set free in New Zealand, a multitude of British forms would in the course of time become thoroughly naturalized there, and would exterminate many of the natives'. ${ }^{17}$

The theory was also instrumental in shaping attitudes with respect to the management and use of the forest resource. ${ }^{18}$ Indicatively, in criticising Premier Sir Julius Vogel's ${ }^{19}$ forest conservation proposals in 1874, John Sheehan, in the House of Representatives, alluded to a 'mysterious law' that meant that 'the moment civilization and the native forest come into contact, that moment the forest begins to go to the wall' ${ }^{20}$ Roche in his study of forest policy concludes that the implications of such faith were long-term and fundamental. As he puts it: 'importantly in the longer term was the way in which [the Popular and Official views, influenced by the displacement theoryl ... shaped a limited view of forestry ... which emphasised tree planting and not the sustained harvesting of natural forest'. ${ }^{21}$

There is persuasive evidence that for nineteenth-century New Zealand settlers the displacement theory was not only predictive but also normative. ${ }^{22}$ Darwin theorised that because "hardly a single inhabitant of the southern hemisphere has become wild in any part of Europe...the productions of Great Britain stand much higher in the scale than those of New Zealand'. ${ }^{23}$ By 1859 , settlers had assumed a status as 'the dominant people of the land'. ${ }^{24}$ As part of the normal process of scientific and social advancement of this dominant race, it was both appropriate and necessary that decadent natives be replaced by superior Europeans, or in some cases their numbers controlled. Only those natives that met European standards would be granted commensurate legal status (notable examples being the paradise duck (pari), swamp hen (pukeko), and pigeon (kereru) that all enjoyed the dubious prestige of being classed as game). 
By way of contrast, the shag (kawau) could be shot at any time because of its predation on imported trout. The kea (a native parrot) was similarly targeted for its liking for sheep. As one contemporary writer explained in the latter case, so severe did the nuisance become that the aid of the Legislature had to be invoked for the purpose of extirpating the bird'. ${ }^{25}$ The Otago Acclimatization Society offered bounties for the destruction of hawks and kingfishers for their effect on introduced species, ${ }^{26}$ while the native trout (kokopu) faced competition from the aggressive imported varieties (both Rainbow and Brown).

It was against this historical background of enthusiastic and widespread acclimatisation that various attempts were made to introduce the rabbit, both as a source of food and fur and as game. The first attempts proved to be failures or achieved only limited success; the animal could not survive the different climatic and vegetation conditions. However, the introduction in Southland in 1864 of wild rabbits that behaved in the proverbial way" ${ }^{27}$ was to prove successful beyond the wildest dreams or nightmares of those involved or affected. By the 1870 s a population explosion of these animals threatened the viability of pastoral farming in New Zealand (the wool industry then providing the 'backbone' of the economy). A hunt was on for a solution.

\section{THE RABBIT NUISANCE - A CHOICE OF SOLUTION}

In 1875, the Provincial Superintendent appointed a Commission of Inquiry *into the extent to which the rabbit nuisance prevails in Southland.${ }^{2 x}$ Words employed in the Commission's report (tabled in May, 1876) to describe the rabbit and its depredations conveyed urgency and desperation - 'nuisance'. 'evil', 'infested' and 'calamities'. This impression was reiterated in the conclusion: 'if the public estate is to be rescued from serious depreciation, and private interests from calamities and losses, in no small measure the results of an outside visitation ... this can only be obtained by the application of a remedy which shall be immediate. compulsory and universal' ${ }^{20}$

In hindsight it seems almost inevitable that this 'remedy' should have been identified as biological, an inevitability reflected in the rapid identification of mustelids as the best chance of controlling the pest and restoring 'the balance of nature . However, their advocacy was to quickly prove controversial. Although there were various individuals involved in this debate in a range of official and popular contexts, its focus and significance can best be introduced by way of two of the original parties, Professor Alfred Newton, Professor of Zoology at Cambridge University, and the man he described as both thoughtless ${ }^{\circ}{ }^{30}$ and 'a fool'. ${ }^{31}$ Frank Buckland. 


\section{THE ZOOLOGIST AND THE 'FOOL'}

Shortly after the Commission reported back, Macrorie and Cuthbertson, an Otago-based firm of stock and station agents, wrote to Frank Buckland, an English acclimatisation enthusiast ${ }^{32}$ asking for weasels to be sent to New Zealand, where pastoralists were willing to offer $£ 5$ a pair. ${ }^{33}$ In his column, Buckland expressed the opinion that 'no doubt the weasels would kill a great many rabbits, but I believe they are more enemies to rats, mice and small birds ${ }^{34}$ He went on to suggest that. given the difficulties in keeping weasels alive in captivity, ferrets would be a better option.

Despite having little time for Buckland, Newton sent him a letter of protest, warning of the devastating consequences of importing weasels or like species to New Zealand. 'No person ... can for a moment doubt that what remains of this [native] fauna will absolutely and almost instantaneously disappear ... Even if it be doomed why should we hasten its end?' Newton also wrote to such leading New Zealand scientists as Sir James Hector, ${ }^{35}$ Walter Buller and Frederick W. Hutton, ${ }^{36}$ urging prevention of this 'disastrous importation'. Buckland responded to Newton's concern by including the script of his letter in his column and commenting on it as follows: 'I should be exceedingly sorry to do anything to injure the natural history of our friends in New Zealand, and shall therefore take the admonition of Professor Newton and pause a while before sending out the ferrets to New Zealand'. ${ }^{37}$

However, he also referred to a 'friend... who has lived a good many years in New Zealand' as a 'practical sheep farmer', who was in favour of introducing ferrets to 'let the sheep have their proper share'. In another place, he asked that if not advisable to send ferrets to New Zealand, 'would [Professor Newton] and the naturalist whose opinions he represents, be kind enough to suggest some practical remedies by which the rabbits may be kept under? ${ }^{3 *}$

Newton's and other expressions of opposition to the proposal (reproduced by Buckland in his Land and Water column the following week) suggest a growing awareness on the part of the British scientific community of the fragility of the New Zealand ecosystem and of the importance of its preservation. For example, noted ornithologist and naturalist Mr James E. Harting framed his opposition thus: I tremble to think of the fate of the pheasants .... But ... I plead not so much on behalf of acclimatised game birds as on behalf of the native avifauna: ${ }^{39}$

'XYZ' blamed 'gamekeepers. [who] killed hawks to conserve pheasants' +0 for the rabbit problem and went on to accuse the owners of game preserves of destroying 'the weeka [sic] rails by hunting them with greyhounds. in order to make room for the pheasants'. George D. Rowley went further in describing 'such a mistake (introducing polecats) as much I should look upon a proposition to run a railway through Westminster Abbey on Utilitarian principles'.+1 
The two opposing positions were thus revealed: for Buckland and his New Zealand correspondents (for whom the views and economic needs of 'practical' farmers were of primary importance) sheep outclassed birds. For Britishbased academics and naturalists, New Zealand represented a unique ecosystem. worthy of preservation and protection. The only question that remained to be decided was: who would win on a rabbit-sick New Zealand pasture? Despite a ubiquitous discourse of change, it was not quite a forgone conclusion. Instead. opposition to the proposal to introduce these predators sparked a parliamentary initiative to prevent it.

Newton had directed his initial plea to Hector (then Director of the New Zealand Geological Survey and Colonial Museum, and the Manager and Editor of the New Zealand Institute). In his absence, Hon.Walter B.D. Mantell, a member of both the Philosophical Society and Legislative Council and with a 'passion for natural history', ${ }^{42}$ took prompt action in both Houses of Parliament. Action was taken in the House of Representatives through Sir George Grey, ${ }^{43}$ then a member of a disparate opposition.

Mantell's and Grey's original intention was to push through an amendment to $\mathbf{2} 29$ of the Protection of Animals Act 1867 so as to add polecats, stoats and weasels to the list of prohibited imports. In moving the second reading of this amendment, Grey focused on the hazard posed by mustelids to birds, particularly insectivorous ones. According to 'eminent naturalists', he explained, the most undesirable of the family were weasels, given they 'would materially interfere with the agriculture of the country' because they would kill the birds which destroyed the grain-eating insects. ${ }^{44}$

This was clearly a strategy appropriate to a House with a majority of small farmers, who valued birds of any stripe for their role in controlling crop-damaging insects. ${ }^{45}$ However, Arthur P. Seymour (Wairau) argued in the present case that "rather than being a Protection of Animals Act it was a Noxious Animals Prohibition bill' ${ }^{46}$ This initiative (to have such animals subject to a prohibition-focused new statute rather than within existing 'protectionist' legislation) had the implication that species could and should be exempted if deemed on balance to be useful rather than injurious. Accordingly for Seymour, stoats and weasels should not be considered noxious because 'it had been suggested in many places that the true mode, and perhaps the only mode open to them [the pastoral farmers] to prevent the increase in rabbits was by the introduction of these animals ${ }^{47}$ (albeit with a possibility of harm to other fauna protected under the Protection of Animals legislation).

Similarly, during the committee stage, those opposing its coverage proposed a series of amendments to exempt foxes (Edward Wakefield), polecats, stoats and weasels (John C. Wason) and weasels (John C. Andrew) on the basis that their economic value exceeded their noxiousness. It is perhaps indicative of the strength of feeling in the House against these importations that the amendments were all defeated and an overwhelming majority ( 38 to 9 ) agreed that the clause 
banning the importation of noxious animals should remain unchanged. The bill passed its second and third readings on the same day and was referred to the Legislative Council.

During his introductory speech in the Council, Mantell took some care to contextualise it as a measure that 'merely provided for an increase in the protection of our native and imported birds and other animals by the extension of the prohibition of the importation of noxious animals' (to include specifically polecats, stoats and weasels). ${ }^{48}$ No doubt mindful of the domination of the Council by the pastoralists (of the 35 members, 19 are identified as farmers ${ }^{49}$ - mostly pastoral), he sought to garner support for the amendment by drawing support from 'good authority' that mustelids would be of no avail in solving 'what might be called a rabbit scare amongst gentlemen of the pastoral persuasion ${ }^{50}$ Hon. George S. Whitmore from the Hawkes Bay endorsed Mantell. warning that in a short time [mustelids] would be a much greater nuisance than the rabbits themselves', ${ }^{1}$ as did Hon. William H. Nurse (from Southland) who described himself as 'a practical farmer' ${ }^{52}$ and Hon. William Robinson from Nelson. ${ }^{53}$ However, those speaking in opposition to the measure sought to disarm its proponents by discounting the predictions of disaster. For example. Hon. Mathew Holmes from Otago ${ }^{54}$ asked whether there were 'any birds worth preserving in this country?' They only had a few parrots and the kiwi. Anyway, surely these messages of doom were excessive - 'birds had not been destroyed in England [where these predators were common], why should they here? ${ }^{55}$ Hon. Captain Thomas Fraser, also from Otago, clearly ranked fauna in order of relative value with his comment that he was 'very fond of birds, but if it came to a question of whether he would have birds or sheep he would certainly vote in favour of the sheep. He would be delighted to see a shipload of stoats' ${ }^{56}$ Finally, and somewhat ironically in view of his sponsorship in the House nine years previously for protection of 'useful' indigenous species, for the now Hon. John Hall, native fauna was not even worth a mention. Instead, mustelids "would do more good than harm [because] the only harm which he understood .... was that they would attack some of the introduced game' (thereby 'interfering a little with the pursuits of sporting men'). ${ }^{57}$

Mantell was probably prepared for such opposition from those Councillors from areas most affected by the rabbit plague, but may well have listened to two other speeches with a sinking heart, realising that, even if a majority were willing to take steps to control the importation of mustelids for the future, it may be too late. Firstly, Hon. George M. Waterhouse, a pastoralist from Wellington, after claiming 'that they were all agreed that it was desirable... to facilitate the acclimatization of animals that might be useful to man' (including weasels), revealed that 'he had, within the last three or four months, turned loose a considerable number of ferrets' ${ }^{58}$ while the Hon. Dr Daniel Pollen of Auckland confessed to having 'some weasels in his possession'. 59 
Nevertheless, the bill went to Committee, where a proposal to amend the measure to exempt weasels from its coverage was defeated, but only by virtue of the Chairman exercising a casting vote. The bill then passed its second reading by the smallest of margins (14-12). At this point, however, its advance came to an abrupt halt. Clearly, its passage was not considered urgent given that it was committed for its third reading in six months.

It is important that this political initiative was unlikely to have emerged in a vacuum. King makes the point that Mantell's attempt to ban these species must have been spurred at least in part by strong expressions of opposition from local ornithologists as well as from Newton. This is of interest in itself as it appears to run counter to the facilitation of change. One of the few published examples of such opposition is a paper presented by Buller two months after the bill had been committed. This paper is of note for two reasons. One is that Buller refers to the Legislature 'having rejected' the proposal to ban the importation - a reference that suggests that although theoretically it was not due back to the Council for several months, it was by this time clear the bill would advance no further. Secondly, Buller describes the proposed introductions as "one of the worst predaceous vermin', quoting from Newton's letter to him in support. ${ }^{60} \mathrm{He}$ then went on to challenge the merits of the case that would 'no doubt' be argued by the other side: 'that sheep are of more practical account to the colony than kiwis and wekas' [woodhens]. ${ }^{61}$ Despite such eloquence there is little indication that this paper attracted attention in either scientific or lay circles; it did not apparently spark any sustained protest against possible importations over the rest of the $1870 \mathrm{~s}$ and in the end it certainly did not deter the advocates of such importations seeking state approval, participation and support..

However, opposition to the proposal to import mustelids was not limited to the scientific community but also emerged in the major Otago newspapers (Otago Daily Times and Otago Witness). The day after reprinting Buckland's earlier pieces from Land and Water, the Times described the acclimatisation as a 'remedy worse than the disease' and expressed the opinion that 'the evil is best settled by such remedial measures as the wisdom of the Assembly has already suggested' (these being manual and direct methods such as trapping and poisoning). ${ }^{62}$ In the same week the Witness carried an editorial roundly condemning the proposal to import 'polecats'. Maybe settlers would not 'regard the extinction of the woodhen with the sentimental regret that a BUCKLAND (sic) would feel for it, but that they would be better off with the rabbit than with the weasel or polecat'. If this importation were allowed, 'it is likely that someone will take a fancy to keep snakes... or alligators.... If not, why not?' In words reminiscent of the old lady and her fly, the Witness called for 'some stop to be put to the endless chain of animals that imagination may suggest might be poured into New Zealand as a cure for some other evil'. ${ }^{63}$

Nevertheless, the opposition of the Witness must be viewed with caution. not necessarily as an attack on acclimatisation of mustelids per se but on an- 


\section{PHILIPPA K. WELLS}

other issue that had a high political and social profile: that of land ownership and occupation. By way of clarification, the theme of both this editorial and that of the previous week was the idle absentee land owner, who embodied the most undesirable characteristics of British tradition. In the first of these editorials, the focus was on the pejoratively-termed 'squatter' deeply indebted to the British-owned banks and other financial institutions. Squatters, argued the editorial, were those:

who buy with money borrowed outside the Colony. It always pays to sell land to men who buy with money saved or brought into the colony by themselves.... In the first case, which is usually the case of the squatter, every shilling wrung from the grudging soil by the toil of the shepherd or the ploughman goes home to feed Lombard St and Kent. In the latter case it... refreshes a whole community. ${ }^{64}$

Perhaps the 'squatters' who sent all profits extracted by the labour of hirelings 'home' [to England], would be the most likely to be tempted to import snakes and alligators purely as rarities and curiosities. These 'idle rich' were also most vocal in demanding assistance from the toilers of the community in solving the rabbit problem. The problem, the Witness maintained, could be solved easily. not by introducing stoats and weasels, but by carving up the estates into smaller farms. ${ }^{65}$ These farms would then provide a good living, not only for the working owner, but also for the community in which they resided - clearly in tune with the 'honest rural toiler as the foundation of the ideal society' thinking of many of the settlers. ${ }^{66}$ The Witness went on to pronounce that 'we may carry our argument even to the length of deprecating the introduction of gamekeepers beyond a certain point. It would be a sad pity to have our old friend of the velveteens' (a derogatory reference to gamekeepers) 'introduced here'.

Despite this (somewhat limited) evidence of support for a ban on mustelids, the Noxious Animals bill that would have realised it never re-surfaced, a fate that may have had several origins. Perhaps, even with the support for the measure in the House, the grudging and ambivalent reception in the Legislative Council was enough to persuade its supporters that the bill would not pass its third reading. Its opponents would have a chance to marshal their forces before it reappeared. Alternatively, or in addition, it is at least possible that the revelations made by Pollen and Waterhouse suggested that the argument against them was now academic at best. Prevention was no longer possible to achieve. It is also possible that political issues of greater moment (most specifically the pending abolition of provincial government) distracted attention from the relatively trivial matter of native species protection.

Whatever the immediate reason for its failure, it remained legal for private individuals to import mustelids on their own behalf, although Government did not as yet take an active part. In addition, the door was left open, once pastoralists regained sufficient power, for changes in policy to be sanctioned. 
By 1881 , when the importation and liberation of mustelids was given specific political sanction rather than merely implicit approval, several developments had helped strengthen the power base of the pastoral sector. First, the onset of an extended economic depression - sometimes called the 'hungry eighties'-led to political pressure for measures to increase employment and national income through exports. As an indication of the degree to which this depression claimed the attention of legislative decision-makers, in 1880 Parliament was called in May (three months early) to hear a financial statement that 'reinforced the gloomy mood and antagonised many MPs ${ }^{\prime}{ }^{67}$ With a continued emphasis on rural commerce (particularly wool), it is inevitable that much attention would be paid to farming. Secondly, the pending introduction of refrigerated shipping ${ }^{68}$ offered some hope to livestock farming, principally that of sheep (as now the meat as well as wool could be offered to the European market), provided productivity could be maintained or improved.

A new report into the rabbit problem, tabled during the 1881 recess by a joint House and Council Select Committee, chaired by Holmes, reflected a heightened degree of political concern with the problems faced by this sector and the need to improve its outlook. Consequently, the report recommended a raft of measures that would, inter alia, shift most legal responsibility (and cost) for management of the rabbit problem from the pastoral sector and locally elected Rabbit Boards to central Government, and, most pertinently, provide 'for the protection of natural enemies of the Rabbit at present in the colony ${ }^{.}{ }^{6.9}$

Witnesses and others who made written submissions to the committee generally supported such a recommendation. For example, two pastoral run-holders (a Mr Fraser, and a Mr Rees) supported any natural enemy provided that enemy did not attack sheep or lambs, while Mr W.C. Buchanan from Carterton (Chairman of the local Rabbit District) poured scorn on any suggestion that they would cause damage, including to lambs. Mr R.F. Cuthbertson suggested that the Indian mongoose be added to the list of possibilities, while Mr G.F. Bullen from Kaikoura believed 'that ferrets will be the salvation of the country'. ${ }^{70}$ Bullen's unconditional support seems odd at first glance, given his recognition of woodhen (weka) as a useful weapon against rabbits, yet one readily and frequently destroyed by the 'hundreds' of ferrets he had personally liberated over the previous eight years. However, it can be rationalised by his connection of solution (ferrets) to the problem (rabbits). Wekas ran a poor second in his estimation to ferrets as obviously superior predators.

A lone voice of opposition was that of Mr Jackson of Featherston. In his view, although tame ferrets were useful in the battle against the rabbit, they should not be liberated because "when they become wild they are very dangerous'. ${ }^{71}$ Stoats, weasels and polecats should not be introduced at all. ${ }^{72}$ As a measure of his concern, he would sooner have a hundred rabbits than a dozen weasels. However, when pressed for an explanation, he could only say that they 'do a great deal of mischief in the old country'. Although that explanation is of 
passing interest because it contradicts a more generally-held opinion that they would on balance be useful, it proved in the end to be of little importance to the Committee's recommendations.

The legislative measure that emerged from this report (the Rabbit Nuisance Act 1881), of most moment in this context for its provision of legal protection for 'enemies' of the rabbit, sparked neither division nor debate in the House of Representatives and virtually no debate in the Council (and that was largely to do with the licensing of dogs for rabbit hunting). Offering further evidence of the level of support is its rapid passage: in the House the bill was introduced on 6 September, went through its committee stage and third reading on the 9 th and passed in the Legislative Council on the 15th. ${ }^{73}$

This support in the House in particular may at first glance seem surprising; after all, electoral reform in 1879 extended voting rights to all adult males rather than just those who held land. Surely, newly represented interests would be more likely to resist rather than support a measure that would benefit pastoralists more than most. Perhaps some rationale for this support can be found not only in the gloomy outlook affecting all aspects of the economy, but also in two immediate occurrences. ${ }^{74}$

The first of these was the pending implementation of socially and politically significant land reform that involved the break-up of the large pastoral estates. No longer would rabbits be a problem only for pastoral farmers; a Government intent on land reform measures would have to become more deeply and directly involved. Indicatively, Holmes (who had chaired the committee), when moving the second reading of the Rabbit Nuisance bill in the Council, emphasised that the Government had both a vested interest in clearing the land, because "it would be impossible for small settlers to live there unless the rabbit-pest was dealt with,${ }^{75}$ and a statutory obligation to do so in relation to unoccupied land.

A second immediate factor was the Representation bill, a measure that altered the basis of defining electorates from numbers and communities of interest to population (which meant that a significant proportion of sitting members were likely to lose their seats), and introduced a 25 per cent 'country quota' (which meant rural electorates had a smaller population base than did the urban). Debate on that bill had occupied the House in a virtually continuous sitting from Tuesday, 23 August to Monday, 6 September, a sitting that involved a large number of divisions, numerous stonewalling speeches and obstructive strategies. It finally passed its third reading in the early morning hours. The House then adjourned at $4.15 \mathrm{am}$. The Rabbit Nuisance bill came up for its second reading at 7.00 the following evening when the House reconvened (and sat until $1 \mathrm{am}$ ). Less than a day's respite from an exhausting marathon scarcely afforded time for any intending opponent to marshal his forces.

The Act empowered the Governor-in-Council to 'declare any animals, the importation whereof is not prohibited ... to be natural enemies of the rabbit, and... prescribe that any such animals shall be deemed to be protected under 
this Act' (s24). The members of the Legislature and the country as a whole were to be left in little doubt as to the identity of such an enemy $-\mathrm{s} 25$ referred specifically to ferrets, weasels or other such animal in providing a penalty for their destruction or capture without the consent of the landowner or Rabbit Inspector (in the case of Crown lands).

It was from that point that the economic benefits that must flow from the presence of mustelids were deemed to be sufficiently great as to demand their official protection, albeit with some acknowledgement that exceptions may be made to that protection. Even those limited exceptions were not to last - a mere one year later, pursuant to the Rabbit Nuisance Act 1882, no longer were individual landowners able to give consent to the destruction of the predators. Only the Rabbit Inspector, empowered under s29, was able to grant such permission, hardly likely to be forthcoming where rabbits maintained an on-going presence. $^{76}$

Of more general moment perhaps, it was from then that the importation of mustelids and their breeding for release was adopted as official taxpayer-funded Government policy, ${ }^{77}$ a policy that resulted in thousands being imported and/or bred for release over the following decade. Between 1884 and 1886 alone. 4000 ferrets, 3099 weasels and 137 stoats were liberated. ${ }^{78}$ Ironically perhaps, the positive effect on the rabbit population in Britain due to this mass emigration led to suggestions that they be returned. Even if there was a chance that the native fauna would therefore be put in peril, it was considered a chance that should be taken in the interests of the country as a whole. However, this is not quite the end of the story. An epilogue offers some hint of the shifting sands on which acclimatisation of these predators was built.

\section{EPILOGUE}

Despite the Superintending Rabbit Inspector reporting mustelids as 'rendering good service' in $1888,{ }^{79}$ the seeds of concern were by that time already sown. Within a few years, those seeds had produced disquiet, as to the presence of these predators, and opposition to their protection. Carrying the analogy further, it is also evident that advocacy in their favour persisted despite efforts at eradication.

The original articulations of disquiet and opposition, although not the only ones to appear in print, came from members of the scientific community. Early examples of statements to that effect that appear in the Transactions, inter alia, predicted that mustelids would spread 'as the rabbit has done'. ${ }^{80}$ In addition, they described the difficulty of protecting the birds against an animal that in Austria 'we destroy .... at every opportunity' ${ }^{* 11}$ (a warning at odds with Holmes and others' dismissal in the Legislative Council of messages of doom), and railed against the 'incredible folly of the Government in turning out ferrets 
on the western shore of Lake Manapouri ${ }^{\times 2}$ (this being a lake in Fiordland, an area covered by dense native bush, exhibiting no rabbit problem but home to thousands of native birds).

Over the following decade such disquiet became louder and more widespread, although even by that time opinions were not consistent. Buller must be considered a prominent figure in this context, although opinions differ on the extent to which he expressed such disquiet and the motivation that drove it. King claims that Buller was 'tireless in his opposition, $\ldots$ and continued to denounce the idea for years after it was too late ${ }^{83}$ By way of contrast, Galbreath claims that after Buller's critique in 1876 he barely mentioned the issue again in his published papers, at least until it suited his purposes. ${ }^{84} \mathrm{I}$ have located seven negative references after 1876 in his addresses in the Transactions (1891 being the earliest of these and 1898 the last), a passing mention in the second edition of the Book on New Zealand Birds (published in 1888), as well as some reference to concerns expressed by his correspondents.

However, these negative references are intrinsically inconsistent. Buller seemed reluctant, at least at first, to single out mustelids from other predators to make a special case. One of the first references (in 1891) was to the effect on thrush of 'diggers' dogs ... wild cats, stoats and weasels ${ }^{\circ}{ }^{, 5}$ and in the same year, while discussing the reasons for extinction of birds on the West Coast, Buller was inclined to blame 'the Norway rat $\ldots$ for much of the mischief' ${ }^{\text {t6 }}$ In June 1894 he railed against the depredations of 'bloodthirsty animals like stoats, weasels and ferrets' ${ }^{77}$ but moderated his comments with an allusion to the 'inscrutable law of nature' - displacement - that caused species to die out 'long before our drastic colonization'.

After 1894, a change to his tone can be detected. ${ }^{88}$ In a paper delivered later in that year, he branded the decision by 'our wise Government' to buy up and import hundreds of these predators as an 'act in the light of a crime', and as 'shipment after shipment of these vermin arrived ... had raised my voice in protest ... but all to no purpose' ${ }^{89}$ The following year, he again condemned the 'insane policy of introducing predatory animals ... in the vain hope of suppressing the rabbit nuisance' ${ }^{90} \mathrm{He}$ contended that this policy was initially adopted in response to the "clamour of a few faddists whose idea was to exterminate the rabbits at any cost ${ }^{,}{ }^{91}$ and in 1896 extended to the effect on kiwi and woodhen [weka] of the 'ravages' of stoats and weasels. ${ }^{92}$ Finally, he made two references in a single address to "predatory animals ${ }^{93}$... thoughtlessly introduced by a too impulsive Government'. ${ }^{94}$

In a footnote to this address, Buller claimed that 'my ... views as to the absolute wickedness of [the introductions] are too well known to need repetition, ${ }^{95}$ perhaps implying that after long and loud protest he was now ready to lay the issue to rest (somewhat at odds with Galbreath's comment). In the same location, he quoted at some length Newton's disgust and anger at the "extraordinary atrocity' wreaked by mustelids on New Zealand's avifauna. ${ }^{96}$ 
Whatever motives and dedication can be attributed to Buller, he was not alone amongst members of the Philosophical Societies in denouncing these predators and those responsible for their presence. For example, in 1891 Travers referred to mustelids as having 'to be killed as vermin', ${ }^{77}$ while Rev Peter Walsh exposed an irony in the landowners' advocacy for their importation. Not only had they proved both "an intolerable nuisance ${ }^{198}$ and an abject failure in controlling rabbits, the arrival of those rabbits had reportedly been celebrated by the landowners 'with a champagne lunch'. Similarly, Thomas Kirk (in his presidential address in 1895) talked of the accelerated rate of extinction faced by birds 'of exceptional interest' since the introduction of the stoat, weasel and ferret' $:{ }^{99}$ and Guthrie Smith described the introduction as a "crime ${ }^{\cdot 100}$ Finally, Bathgate positioned his criticism of this 'grave error' in the wider context of the acclimatisers, whose 'zeal was greater than their knowledge' and whose mistakes were 'fraught with evil results'. ${ }^{101}$

Nevertheless, not every member of these societies was singing from the same hymn book. In 1890, Thomas White expressed his disappointment in the Transactions that the Hawkes Bay Rabbit Board had decided against importing weasels. 'The balance of nature', he explained, 'is presently upset...so man is required (italics added) to place the weasel in the opposite scale', ${ }^{102}$ (the implication being that it was not only desirable but a duty owed to Nature for man to import the predator). Another notable example is one Coleman Phillips, entrepreneur, member of the Wellington Philosophical Society and a loyal supporter of acclimatisation of 'useful' species. ${ }^{103}$ In 1888 Phillips kept the minutes of a meeting of settlers of Wairarapa, ${ }^{104}$ where the desirability of introducing ferrets as a control on rabbits was vigorously debated. As he later noted, 'there was such an outcry by the small farmers to the proposal...that I thought it expedient to bend to the storm and oppose the introduction of other ground vermin. ${ }^{105}$ The resultant resolution, moved by Phillips, was 'that the introduction of stoats, weasels, mingeese or fox ... is unnecessary'. ${ }^{106}$ This motion for Phillips had the desired effect as "objection to the ferret practically ceased - it also had the effect of preventing any person thinking of introducing the fox or mongoose'. ${ }^{107}$

Such variance of opinion and position was reflected elsewhere in society over this same period. On the one hand were those pastoral landowners in the 1870 s and early 1880 s who knew that predators were the only effective weapons against the ravages of the rabbit. For them, the benefits flowing from their introduction drowned out any expressions of concern or reservation that might be expressed. Ensuring their on-going 'power and ... influence' ${ }^{\prime 08}$ depended on their making immediate and necessary changes to maintain productivity of the land, and allowing 'insufficient time... for earnest consideration ${ }^{1109}$ of potentially negative consequences further down the line.

By the end of the decade, however, political and economic power had shifted. The pastoral farmer was again facing falling economic fortunes and rising pressures: 'many large holdings ... were mortgaged up to the hilt .... In 
many cases... the land itself, overrun by rabbits with which half-submerged runholders were powerless to cope, was deteriorating ... ${ }^{110}$ Their saviour had failed to live up to expectations. By way of contrast, the proven success of refrigerated shipping (that first began in 1882) had improved viability for smaller agricultural units, while the "political revolution' "I' of 1890 contributed to the power of those employed in the service industries. This trend continued until 'from 1895 onwards ... the change-over from wool to mixed farming for frozen meat, butter and cheese, resulted in closer settlement and the rise of new industries such as freezing works, butter and cheese factories and other processing plants'.112

These sectors of society, who now held economic power, possibly had little first-hand knowledge of the rabbit problem experienced by the pastoralists. It is also possible they did not really care much about it. With the basis of their prosperity in industries other than wool, they were still expected to contribute to the costs of rabbit control. It would hardly be surprising should they be prepared to accommodate values beyond that of grassland productivity and expect their elected representatives to promote them.

Amongst such representatives were those scientist-politicians who featured prominently in native specie protection efforts from the early 1890 s onwards. Examples of such individuals in the House included Harry Ell, who pushed for the creation and protection of scenic reserves, George Thomson, an erstwhile acclimatisation supporter who became a vocal critic of particular instances. and Alfred Newman who helped lead the campaign to establish Tongariro National Park. Most particularly in this context, Thomas MacKenzie (who a year later advocated the reservation of Fiordland as a National Park) was to declare bluntly his condemnation of mustelids in 1893, when a member for Clutha and opponent and vocal critic of the ruling Liberal Government: 'Past Governments and the present Government had liberated throughout the length and breadth of the country weasels and ferrets, which were doing no good in the way of the destruction of rabbits, but were ... destroying every bird they came into contact with'.113

Despite this increasingly vocal condemnation and emergent hostility to their presence both inside and outside Parliament, it would be for a further decade before the first steps would to be taken against mustelids, with a particular focus on their protected status as enemies of the rabbit. These first moves were ultimately followed by the removal of all protection, although that process was to prove both glacial in pace and torturous in contrivance, involving four separate steps over a fifty-year period.

The first hint that the time was ripe for consideration of the issue can be found in a question put to the Minister of Lands (Hon Thomas H. Young) by Francis Mander, Member for Marsden, in July 1903. He asked 'whether the Government will consider the necessity of removing fines for destroying [devastating] stoats and weasels in the North of Auckland? ${ }^{\prime 14}$ While Young deemed it unnecessary 
to change the law in this respect, as there had 'not been a single prosecution' for their destruction (revealing a somewhat flexible official attitude towards the enforcement of the Rabbit Nuisance Act 1882), Thomas Duncan (member for Waitaki) was of the opinion that the effect of removing the fine for their destruction would be to leave the country 'desolate'. ${ }^{115}$ Nothing further was said on the question at this point but the issue was certainly not laid to rest: a mere two months later an amendment was moved to the Animals Protection Act 1867. This amendment would authorise local authorities or acclimatisation societies to petition the Governor for an Order-in-Council declaring that 'natural enemies' 'which have since proved to be enemies of game and poultry, may be killed within the district defined by the order'. ${ }^{116}$ It should, perhaps, be noted that the focus of the amendment, and consequently the theme of speeches for the bill, was narrow; limited to specific areas, requiring overt action on the part of the bodies concerned and on the protection of game, rather than native fauna in general. William F. Massey pointed to the rapid disappearance of the pheasant. ${ }^{117}$ and Archibald D. Willis to the 'insufferable nuisance' posed by the stoats and weasels to the native game. ${ }^{118}$ Ell from Christchurch also spoke of the destruction of ground game by stoats and weasels that he described as "brutes. .119

By way of contrast, those opposed to this aspect of the amendment spoke in wide terms, holding fast to the virtue historically granted mustelids as economic necessities, and correspondingly anxious to remind the House of the 'enormous benefits conferred by the introduction ${ }^{120}$ and their 'importance to the settler'. ${ }^{121}$ Of particular note in this context, Bennett dismissed Ell's negative remarks on mustelids as those of a purported 'authority on things he knows nothing about' and hoped that the Minister would "never consent to do away with these "vermin" ... until the rabbits are entirely exterminated. ${ }^{122}$ As what was proposed fell far short of 'doing away' with the mustelids, it is easy to dismiss this statement as mere political hyperbole.

At the same time however, his statement suggests an undercurrent of concern amongst advocates of the 'vermin', and of heightened negative sentiment, most particularly disillusionment and antipathy. That such concern was not unfounded is evidenced by the move by Government away from active involvement in Mustelidae breeding, distribution and use for rabbit control (a move that more than merely hints at disillusionment with their suitability and effectiveness). A degree of antipathy is suggested not only by the successful passage of this amendment through both houses, but also by the somewhat acerbic classification, by Hon. John Rigg, of parliamentarians 'along with the stoats and weasels and the polecats and other pests of that kind', ${ }^{123}$ when speaking to the Industrial Conciliation and Arbitration bill (the debate having followed the third reading of the Animals Protection Amendment Act).

As a conclusion to this historical saga, this 1903 measure was to prove symbolic in terms of the political status of mustelids in New Zealand. It also marked the beginning of an inexorable, albeit painfully drawn-out, slide in their status 
as the pastoral farmers' champions in the battle against rabbits. ${ }^{124}$ They were no longer a solution but a problem: sparking an enduring (and continuing) search for means of defending the indigenous 'aristocrats of the Animal Kingdom' from the 'shrewd, vulgar,...cunning,...greedy and ferocious invaders', ${ }^{125},{ }^{126}$ and for strategies whereby their numbers might be controlled. ${ }^{127}$

Finally, how does the fall from grace of mustelids fit within the wider discourse that shaped acclimatisation practice and theory as New Zealand moved into the twentieth century? Some indication can be obtained through an examination of the rationale and extent of shifts in that discourse.

\section{REFLECTION - SHIFTS IN A DISCOURSE OF ACCLIMATISATION}

Perhaps more than merely by chance, the redefinition of mustelids in the discourse of the 1890s and beyond coincided with two developments. First, from late in the nineteenth century, both professional scientists and amateur practitioners began to doubt the value of displacement as a theoretical construct. Secondly, protectionist sentiments gained acceptance in the broader New Zealand society.

Insofar as the Displacement Theory is concerned, although it would appear that Buller and others drew on the predictive aspect of the theory in formulating arguments for conservation by way of island reserves during the $1890 \mathrm{~s},{ }^{128}$ by the beginning of the twentieth century observers were challenging its inherent logic. Thomson (1900) concluded that 'some native species appear to be holding their own, and even to benefit by those attendant circumstances', ${ }^{29}$ while Leonard Cockayne (1901), Kirk (1895) and James Drummond (1907) were ready to brand such theorising as 'spurious'. ${ }^{130}$ Other field observers also highlighted the divergence between reality and the theory, with one of them speaking of Nature's display of 'a marvellous power of resistance and recuperation', despite the damage caused by fire and cattle. ${ }^{131}$

It is important to emphasise that many of the reservations now expressed with the theory were not concerned with species decline; on the contrary, it was clear that many species, previously endemic, were now scarce or extinct. However, both professional and amateur naturalists were now challenging the old explanations offered for their decline. Potts is notable in being one of the first to change his view on the inevitability of decline of indigenous species; he later posited human (European) influences as a direct cause, ${ }^{132}$ although support from others was not immediately forthcoming. ${ }^{133}$ Guthrie Smith, with no formal qualifications but with his years of careful observation behind him, also ascribed to the view that such displacement was a consequence of the loss of habitat brought about by settlers. As he was to write, "woodland species cannot live without woodland, jungle and swamp-hunting birds cannot survive without jungle and swamp'. ${ }^{134}$ 
More specific to the matter of acclimatisation, by the later $1890 \mathrm{~s}$, members of the same scientific community that earlier facilitated change through this process had shifted their position dramatically, now denouncing specific introductions as destructive and wrong. They placed the blame for that destruction squarely on the European (British) settler. At the same time and as part of the same logic, many of these members both contributed and lent support to a heightened popular perception of native species as worthy of protection, rather than weak, decadent and without value.

The emergence of such protectionist sentiments have been attributed to a range of factors, including the emergence of a New Zealand-born generation, who perceived the country as a separate and distinct place, with its own worthy characteristics, that should not be threatened by ill-considered importations. ${ }^{135}$ Indicatively, the anonymous writer of a piece published in the Otago Witness in 1894 lamented the failure of colonists to "be content with what they found here, without importing creatures that exterminate the natives'. ${ }^{136}$ Similarly, in a letter to the Otago Daily Times in 1900, 'Disgusted' branded the barn owl as an example of 'rubbish and vermin' that should therefore never be introduced. ${ }^{137}$. Bathgate's suggestions that the antelope, eland, shrew and toad would have been better imports than were mustelids were not taken further, while the escape of a pair of racoons, imported for their curiosity value to the Government Gardens in Rotorua, caused much official consternation in 1903. This consternation only subsided on the discovery of their dead bodies several weeks later.

Despite this heightened awareness of the potential implications of acclimatisation for the protection of the native flora and fauna, however, it continued to be pursued deliberately through the twentieth century. But it followed a somewhat narrower mandate of refinement or enrichment rather than change, and pursued a pace more reminiscent of trickle than flood. Attention was increasingly turned on species deemed 'useful', a few prominent examples being the possum (for fur), hawks and magpies (to control rodents and insects), game (including pheasants, Canadian geese, deer, chamois, thar and trout that could be used to attract tourists to reserve areas that were otherwise considered waste) and, at least for Sir James Hector, the American kit fox which, he considered, would have been very useful in spreading tapeworm, a rabbit parasite. ${ }^{138}$ As a final indication of its enduring enthusiasm, with the financial and official encouragement of Prime Minister William F. Massey and Hon. Robert Heaton Rhodes (Minister of Tourist and Health Resorts), a heather-planting programme was undertaken in the Tongariro National Park between 1912 and 1919 by the man who would be appointed as the first ranger in 1916: John Cullen. He aspired to create an antipodean Scottish shooting moor. Although game birds never became established, problems with the heather persist into the present. 


\section{CONCLUSION}

Although the proposal to import 'shiploads' of predators to control the rabbit population generated a surprising level of concern about the potential effect on the avifauna of New Zealand, the political, economic and social characteristics of the time provided overwhelming support for introduction. Even though those seeking to prevent the importation came close to achieving a political ban in October 1876, victory may well have proved pyrrhic and short-lived: mustelids were already in the country (albeit not in great numbers) and the opinion in favour of their introduction would prove unstoppable. It is tempting to speculate on the possibility of a different outcome had the issue arisen twenty years later. On one side of the scale, public and political support for conservation and concern over ill-considered introductions had increased, while the economic power base had shifted and the scientific rationale for acclimatisation had been deconstructed and found wanting. That may have provided sufficient cause for careful and considered thought on the question. On the other side, however, must be placed the continued enthusiasm for the introduction of 'useful' species, the inadequacy of mechanical means of controlling the rabbit problem, and an enduring focus on farming as the backbone of the New Zealand economy. These latter factors may well have tipped the balance.

\section{NOTES}

${ }^{1}$ C. King, Immigrant Killers - Introduced Predators and the Conservation of Birds in New Zealand (Auckland: OUP, 1984): 90.

${ }^{2}$ R.H. Grove, Green Imperialism: Colonial Expansion, Tropical Islands, Edens and the Origins of Environmentalism 1600-1860 (Cambridge: CUP, 1995): 13.

${ }^{3}$ E. Dieffenbach, Travels in New Zealand with contributions to the geography. geology: botany, and natural history of that country, 2 vols, (London: John Murray, 1843) I, 2. judged that colonists in the tropics had become 'decrepit, and degenerated'.

${ }^{4}$ W. Yate, An Account of New Zealand and of the Church Missionary Society's Mission in the Northern Island. (London: R.B. Seeley, 1835): 194

${ }^{5}$ H. Sewell, NZPD (HR), 4 (first series), 1862: 690 when speaking on the Native Lands Bill (No 2).

${ }^{6}$ D. Thom, Heritage, the Parks of the People (Auckland: Lansdown Press, 1987): 72.

${ }^{7}$ A Fellow Passenger. 'To New Zealand with British Birds', Otago Witness. 11 March, (1871): 5 .

${ }^{8}$ For example, a Mr Holloway from the English Labourers' Union (reported in the Otago Witness (1874) 18 April: 10) specified the need for manufactories, trade, commerce and the development of minerals as preconditions for New Zealand to become the Britain of the South, while Captain Cook's reports and species introduction foreshadowed "the way in which New Zealand would service the expanding British and American maritime fleets" ( J. McAloon, 'Resource Frontiers, Environment and Settler Capitalism', in 


\section{'AN ENEMY OF THE RABBIT'}

Environmental Histories of New Zealand, ed. E. Pawson and T. Brooking (Melbourne: OUP, 2002): 52, 66 .

${ }^{9}$ Otago Acclimatization Society, First Annual Report of the Otago Acclimatization Society (1865), quoted in P. Star, 'From Acclimatization to Preservation: Colonists and the Natural World in Southern New Zealand 1860-1894 . (PhD Thesis. University of Otago. 1997): 80.

${ }^{10} \mathrm{M}$. Turnbull and I. McLaren. The Land of New Zealand, heing a Companion Volume to the Changing Land: a Short History of New Zealand. ed. M. Turnbull. (London: Longmans, 1964): 81 .

"M. Fairburn. 'The Rural Myth and the New Urban Frontier. An Approach to New Zealand Social History 1870-1940', New Zealand Journal of History 9(1). (1973): 2. 8.

${ }^{12}$ T. Brooking. 'Use It or Lose It, Unravelling the Land Debate in Nineteenth Century New Zealand'. New Zealand Journal of History 30(2), (1996): 141. 146.

${ }^{13}$ A.W. Crosby, as quoted in R. Galbreath, 'Displacement. Conservation and Customary Use of Native Plants and Animals in New Zealand', New Zealand Journal of History 36(1), (2002): 36,38

14 Star. 'From Acclimatization to Preservation: Colonists and the Natural World in Southern New Zealand 1860-1894`: 126.

${ }^{15}$ N. Clayton, 'Weeds. People and Contested Places', Environment and History 9 (2003): $301,314$.

${ }^{16}$ Sir Joseph D. Hooker (G.C.S.I.. C.B., F.R.S), Ernst Dieffenbach (Professor of Geology and writer). Ferdinand R. von Hochstetter (writer and explorer), William T. L.Travers (lawyer, politician and naturalist). Thomas $\mathrm{H}$. Potts (politician and naturalist) and Sir Walter Buller (ornithologist).

${ }^{17}$ C. Darwin, The Origin of Species by Means of Natural Selection. 6th edn. (London. John Murray, 1899): 152.

${ }^{18}$ It should be noted that indigenous forest or bush was one of the few 'native' resources to be identified, even then of lesser use or value than planted exotic timber. By comparison. most of the other native flora and fauna was considered of little or no value.

${ }^{19}$ Sir Julius Vogel was Premier of New Zealand from 8 April 1873 to 6 July 1875 and 15 February 1876 to 1 September 1876 . He is most known for a nationwide public works programme, achieving the abolition of the provinces in 1876 and for instigating the first conservation strategy, albeit short-lived, for forest resources.

${ }^{20} \mathrm{NZPD}$ (HR), 16. 1874: 351.

${ }_{21}$ M. Roche. 'The State as Conservationist, 1920-60. "Wise Use" of Forests, Lands and Water' in Environmental Histories of New Zealand, ed. E. Pawson and T. Brooking (Melbourne: OUP, 2002): 183, 184. This philosophy was reflected in a report in the New Zealand Herald (23 May 1876:3). 'It will be a specific duty, we believe. to gather information as to the renewal of forests when exhausted.... It is to be hoped that the whole subject of tree planting will be considered.' Evidence suggests that this view persisted in both official and popular circles into the twentieth century.

2 G. Wynn. 'Conservation and Society in Late Nineteenth Century New Zealand", New Zealand Journal of History 11(2) (1977): 136 and Pioneers, Politics and the Conservation of Forests in Early New Zealand'. Journal of Historical Geography 15(2) (1979): 171. 


\section{PHILIPPA K. WELLS}

179; G.H. Scholefield, New Zealand in Evolution: Industrial, Economic and Political (London: Fisher Unwin, 1909).

${ }^{23}$ Darwin. The Origin of Species by Means of Natural Selection: 152.

${ }^{24}$ R. Galbreath, 'Displacement, Conservation and Customary Use of Native Plants and Animals on New Zealand'. New Zealand Journal of History 36(1) (2002): 36.42.

${ }^{25}$ W. Gisborne, Colony of New Zealand, its History, Vicissitudes and Progress. London: E.A. Petherick and Co, 1888): 11.

${ }^{26}$ Star, From Acclimatization to Preservation: Colonists and the Natural World in Southern New Zealand 1860-1894': 90-1.

${ }^{27} \mathrm{C}$. King, Immigrant Killers - Introduced Predators and the Conservation of Birds in New Zealand (Auckland: OUP, 1984): 82.

${ }^{28}$ Commission to Inquire into the Extent of the Rabbit Nuisance in the District of Southland. The Rabbit Nuisance in Southland, Report on, by the Hon. Sir J.L.C. Richardson and W.H. Pearson, (1876) AJHR, H-10: 3, 4.

${ }^{29}$ Commission to Inquire into the Extent of the Rabbit Nuisance in the District of Southland, The Rabbit Nuisance in Southland, Report on: 9.

${ }^{30}$ Newton to Hutton, reprinted in Otago Witness, 28 October 1876: 18.

${ }^{31}$ Newton to Buller, 23 July 1876, quoted in Buller. 'On the Ornithology of New Zealand' a Paper Read before the Wellington Philosophical Society, 22 November 1898, Transactions and Proceedings of the New Zealand Institute 31 (1898):1, 26.

"In an earlier column ('Trout Farming in Otago, New Zealand', Land and Water, 22 January 1876: 70), Buckland had described himself as an "enthusiast [for trout fishing] at home' and as a member of the Fisheries Preservation Society. In his thesis, Star also notes his erstwhile position as secretary of the by then defunct London Acclimatization Society (129). G. Wynn, 'Remapping Tutira: Contours in the Environmental History of New Zealand', Journal of Historical Geography (1997): 418, 420. mentions that Buckland's acclimatization organisation was founded in 1860 . He also refers to the 'mania for acclimatization in the UK' $(441, \mathrm{n} .11)$.

${ }^{33}$ F. Buckland, 'Weazels for New Zealand' (sic), Land and Water, 8 July 1876: 10. reproduced in Otago Witness, 9 December 1876: 21.

${ }^{34}$ Buckland, 'Weazels for New Zealand': 21.

${ }^{35}$ Director of the Colonial Museum and Geological Survey, founder and Manager of the New Zealand Institute, advisor to the New Zealand Government on scientific matters.

${ }^{36}$ The letter he wrote to Hutton was reprinted in the Otago Witness, 28 October 1876 , 18.

${ }^{37}$ Buckland, Land and Water, 15 July 1876, 22. This letter along with Buckland's rejoinder and other correspondence on the issue is included in the reprint in the Otago Witness 9 December:21, after the failed political attempt at prohibition (see also further discussion, infra).

${ }^{38}$ Buckland, Land and Water, 15 July 1876: 22.

${ }^{39}$ Land and Water, 15 July 1876: 22-3.

${ }^{40}$ Land and Water, 15 July 1876:39. The Otago Daily Times, 14 Nov. 1876:2 while clearly opposing the importation (see reference infra) albeit somewhat scornfully described this correspondent as 'rather ignorant ... of the state of things out here ... indeed, he seems to know remarkably little about New Zealand'. 
${ }^{4}$ G. D. Rowley, Land and Water, 15 July 1876:22.

${ }^{42}$ Ministry for Culture and Heritage, The Dictionary of New Zealand Biography VI, ed. C. Orange. (Wellington: Department of Internal Affairs, 1990): 267.

${ }^{43}$ An ironic note must be sounded here. Grey was an enthusiastic advocate and sponsor of acclimatization. Kawau Island in the Hauraki Gulf (that he bought in 1862) became a repository for a range of exotic animals. a range that included possums and brushtailed rock wallabies (both now considered pests), zebras, emus, monkeys and antelopes.

it NZPD (HR), 23, 1876: 273.

${ }^{45} \mathrm{As}$ an interesting aside, the sentiment expressed by Grey was clearly reminiscent of that displayed by John Hall (as member for Heathcote, Canterbury) nine years previously. As Hall had explained, the Protection of Animals bill then under discussion: 'consisted mainly of a consolidation of the present Acts... which had been passed for protecting animals that had been imported into the country at considerable cost and trouble; it was also thought desirable that indigenous animals which were of advantage to the country should be protected'. NZPD (HR), 16, 1867, Part II: 1231.

${ }^{46}$ NZPD (HR), 23, 1876: 274. It was reported back from Committee under that name.

${ }^{47}$ NZPD (HR), 23, 1876: 274.

${ }^{48}$ According to J. Druett. Exotic Intruders, the Introduction of Plants and Animals into New Zealand. (Auckland: Heinmann, 1983): 170-1, the first ferrets arrived in New Zealand in 1867, imported by a Mr Morton and kept on his behalf by the Canterbury Acclimatization Society in the Domain Gardens. Stoats and weasels were first officially introduced in 1885 .

${ }^{49}$ W.K. Jackson. The New Zealand Legislative Chamber, (Dunedin: UOP. 1972): App IV, 234-5.

so NZPD (LC), 23. 1876: 609.

st NZPD (LC). 23, 1876: 610. Interestingly. Whitmore had been the part-owner of a large sheep-run near Napier since 1861 .

52 NZPD (LC), 23, 1876: 612.

53 Robinson was also a pastoral runholder.

${ }^{54}$ One of those areas most affected by rabbits.

${ }^{55}$ NZPD (LC). 23. 1876: 612 .

${ }^{56} \mathrm{NZPD}$ (LC). 23, 1876: 609

${ }^{57}$ NZPD (LC). 23, 1876: 610

${ }^{5 x}$ NZPD (LC), 23, 1876: 612. It is worth noting that although specific bans (mainly of diseased animals) were in place at this time, it was not until much later that recognition was given to the necessity of controlling the species introduced into New Zealand.

${ }^{59}$ NZPD (LC). 23. 1876: 609. Pollen did not apparently have any direct connection with farming. 'One of the earliest Auckland settlers'. he became a Government agent in Auckland. (W. Gisborne. New Zealand Rulers and Statesmen (London: Sampson Low. Marston and Company, 1897: 263.)

${ }^{60}$ W.L.A. Buller 'On the Proposed Introduction of the Polecat into New Zealand' Transactions and Proceedings of the New Zealand Institute 9 (1877): 634. 635

6. Buller 'On the Proposed Introduction of the Polecat into New Zealand'Transactions and Proceedings of the New. Zealand Institute: 634.635. 


\section{PHILIPPA K. WELLS}

${ }^{62}$ Otago Daily Times, 14 November 1876: 2.

${ }^{63}$ Otago Witness, 18 November 1876: 13.

of Otago Witness, 11 November 1876: 13. I could find very little coverage in any other of the major papers in either 1876 or 1881 on the question of the importation of these predators into New Zealand. Even the Christchurch Press (despite being published in Canterbury, an area affected by rabbits) apparently did not see the issue as sufficiently important to warrant their attention.

${ }^{65}$ It is of passing interest that this mooted solution to the problem of rabbits is at odds with the conclusion of the commissioners in their report. They believed that the problem of rabbits would be worse under such a scenario because the occupiers would have fewer resources for the battle than did the pastoral holders.

${ }^{66}$ M. Fairburn, 'The Rural Myth and the New Urban Frontier. An Approach to New Zealand Social History 1870-1940, New Zealand Journal of History 9(1) (1973): 3: T. Brooking. 'Use It or Lose It. Unravelling the Land Debate in Nineteenth Century New Zealand', New Zealand Journal of History 30(2) (1996): 141.

${ }^{67}$ J.E. Martin, The House, New Zealand's House of Representatives 1854-2004, (Palmerston North: Dunmore Publishing in association with the Clerk of the House and the History Group. Ministry for Culture and Heritage. 2004): 82.

${ }^{68}$ The first freezer-ship (S.S. Dunedin) left New Zealand for England in 1882. Of the entire cargo of frozen sheep carcasses, only one was rejected on landing.

69) Rabbit Nuisance Committee, Rabbit Nuisance Committee, Report of the. (1881) AJHR, 1-6.

${ }^{70}$ AJHR: 18.

${ }^{71}$ AJHR: App C, 9.

${ }^{72}$ AJHR: App C, 10.

${ }^{73}$ NZLC Journals and Appendices, 1881-2: 279.

${ }^{74}$ Interestingly, based on Jackson's data (The New Zealand Legislative Chamber. 234-5). the proportion (although not the number) of farmers in the Chamber fell between 1876 and 1881 - from 19 out of 35 to 19 out of 43 . However, this shift did not have any negative effect on the level of support for the measure as sufficient of the recently appointed members had connections to pastoral farming (at least two) or political reasons for favouring the measure (at least two).

${ }^{75}$ NZPD (LC), 40, 1881: 514.

${ }^{76} \mathrm{O}$ passing interest are the words used by Hon. Richard Oliver when moving the second reading of this bill in the Legislative Council. The new Act. he explained 'would protect [ferrets] from being molested by strangers'. (NZPD (LC), 43. 1882: 598.

${ }_{77}$ By 31 July 1883 the Superintending Inspector was able to report on the setting up of breeding establishments at three locations (B.P. Bayly The Rabbit Nuisance. Annual Report on. (1883) AJHR. H-18: 1 and by July 1884 on the release of nearly 4.000 ferrets that 'in some places are said to be doing good work' (AJHR, H-2: 2).

${ }^{78}$ Rabbit Biocontrol Advisory Group. A Hundred Years of Rabbit Impacts, and Future Control Options (Wellington: Ministry of Agriculture and Fisheries, n.d.), first retrieved from http://www.maf.govt.nz/mafnet/publications/rabbit-biocontrol-advisory-group/ rbag0010.htm\#E10E60, 16 May 2006)

${ }^{79}$ A. J. P. Thomas, Report on the Rabbit Nuisance, (1888) AJHR. H-18: 2.

Environment and History 12.3 
${ }^{80}$ H.B. Martin, 'Objections to the Introduction of Birds of Prey to Destroy the Rabbit', Transactions and Proceedings of the New Zealand Institute 17 (1884): 179. 182.

${ }^{81}$ A. Reischeck, 'Observations on the Habits of New Zealand Birds, their Usefulness or Destructiveness to the Country'. Transactions and Proceedings of the New Zealand Institute 18 (1885): 96, 103.

${ }^{82}$ E. Melland, 'Notes on a Paper entitled "the Takahe in Western Otago" by Mr James Park F.G.S.', Transactions and Proceedings of the New Zealand Institute 22 (1889): 295, 299.

${ }^{83}$ King, Immigrant Killers: 85.

${ }^{84}$ Galbreath, 'Colonization, Science and Conservation: the Development of Colonial Attitudes toward the Native Life of New Zealand, with Particular Reference to the Career of the Colonial Scientist Walter Lawry Buller (1838-1906)': 134. Galbreath remarks that Buller really only referred to the matter again when involved in the campaign to establish off-shore reserves, and, given his enthusiastic involvement in the collection of (dead) specimens for Rothschild, questions his motive in doing so.

${ }^{85}$ W.L.A. Buller, 'Further Notes and Observations on Certain Species of New Zealand Birds (with Exhibits)', Transactions and Proceedings of the New Zealand Institute 24 (1891):75, 75 .

${ }^{86}$ Proceedings of Otago Institute, 'Paper Read by J. Richardson on the Extinction of Native Birds on the West Coast' 11 August, Transactions and Proceedings of the New Zealand Institute 24 (1891): 713.

${ }^{87}$ W.L.A. Buller, 'Illustrations of Darwinism or the Avifauna of New Zealand Considered in Relation to the Fundamental Law of Descent with Modification', Read before the Wellington Philosophical Society, 27 June 1894. Transactions and Proceedings of the New Zealand Institute, 27 (1894): 75, 96.

${ }^{88}$ Perhaps more than coincidentally, around the time of increasing scientific scepticism as to the theoretical basis of displacement, see discussion infra, and around the time Buller got involved in pressing for the establishment of off-shore reserves (n86).

${ }^{89}$ W.L.A. Buller, 'Some Curiosities of Bird-life', Transactions and Proceedings of the New Zealand Institute. 27 (1894): 134, 137.

${ }^{90}$ W.L.A. Buller, 'Notes on New Zealand Ornithology, with an Exhibition of Specimens', Transactions and Proceedings of the New Zealand Institute 28 (1895): 326, 327.

${ }^{91}$ Buller, 'Notes on New Zealand Ornithology, with an Exhibition of Specimens'. (1895): 329.

${ }^{92}$ W.L.A. Buller, 'On the Ornithology of New Zealand', Transactions and Proceedings of the New Zealand Institute 29 (1896): 179, 193 and 203.

${ }^{93}$ W.L.A. Buller, 'On the Ornithology of New Zealand', Transactions and Proceedings of the New Zealand Institute 31 (1898): 1, 26.

${ }^{94}$ Buller, 'On the Ornithology of New Zealand', (1898): 1,4.

${ }^{95}$ Buller. 'On the Ornithology of New Zealand', (1898): 26.

${ }^{96}$ A. Newton, assisted by H. Gadow, A Dictionary of Birds (London: Adam and Charles Black, 1896): 224-5.

${ }^{97}$ W.T.L. Travers, 'Comment on W.L. Buller, Further Notes and Observations on Certain Species of New Zealand Birds' (Transactions 72), Transactions and Proceedings of the New Zealand 27 (1891): 699. 
${ }^{98} \mathrm{P}$. White, 'The Effect of Deer on the New Zealand Bush; a Plea for the Protection of our Forest Reserves', Transactions and Proceedings of the New Zealand Institute 25 (1892): 435, 435.

${ }^{99} \mathrm{~T}$. Kirk, 'The Displacement of Species in New Zealand. Presidential Address to Wellington Philosophical Society, 3rd July 1895', Transactions and Proceedings of the New Zealand Institute 28 (1895): 1, 7.

${ }^{100}$ H. Guthrie Smith Tutira, the Story of a New Zealand Sheep Station, 3rd edn. (Edinburgh and London, 1953): 354.

${ }^{101}$ A. Bathgate, 'Notes on Acclimatization', Transactions and Proceedings of the New Zealand Institute 30 (1894): 266, 270.

${ }^{102}$ T. White, 'On Rabbits, Weasels and Sparrows', Transactions and Proceedings of the New Zealand Institute 23 (1890): 201, 204.

${ }^{103}$ Indicatively, some years later and in a different context, Phillips was to write: 'I am utterly sick and tired of reading the lamentable effusions of a few extremists who wish to stop all progress for the sake of unattractive Native scenery or a few useless Native birds. I have been over sixty years in New Zealand and never found any practical advantage in either...' (From C. Phillips to the Editor. Otago Daily Times, 16 April 1925).

${ }^{104}$ Held on 28 June 1888.

${ }^{105}$ Written as an Annotation to the Minutes, 1890.

${ }^{106}$ Resolution 16.

${ }^{107}$ Written as an Annotation to the Minutes, 1908.

${ }^{108} \mathrm{King}$, Immigrant Killers: 85-6.

${ }^{109}$ Ibid.

${ }^{110}$ Morell, Britain and New Zealand: 28.

II J.E. Le Rossignol and W.D. Stewart, State Socialism in New Zealand (London: Harrap): 19 , describe the 'legislation of the past twenty years' as socialistic 'in that it has been brought about by a political uprising of the middle and lower classes against the rich'. However, R.H. Hutchinson, The 'Socialism' of New Zealand (New York: New Review Publishing Association, 1916): 9 describes it as being 'in another sense... no revolution, for though the seat of power may have been shifted, the economic and political structure... remained the same. Dominance had merely been transferred from the shipping companies back to the farmers; but this time it was to the smaller farmers who had enlisted the city labourers in their cause.'

${ }^{112}$ According to B.B.M. Pickering, 'State Policy and Hydro Electricity in New Zealand' (M.A. Thesis University of New Zealand, 1949): 85-6 (citing J.B. Condliffe, New Zealand in the Making (London: G.Allen and Unwin, 1930). W.P. Morell Britain and New Zealand (London: Longmans, Green and Company, 1944): 31-2 explains it thus: "closer settlement was achieved not so much by the taxation or repurchase of large estates as by a new extension of small farms', a development made feasible by the introduction of refrigeration in 1882 .

${ }^{113} \mathrm{He}$ was pleading for rangers to police areas of native bush against wanton destruction through fire. His motion included native birds but 'he acknowledged that very little could be done', (NZPD (HR), LXXIX, 1893: 262).

114 NZPD (HR), 124, (1903): 71.

115 NZPD: 71. 


\section{'AN ENEMY OF THE RABBIT'}

${ }^{116}$ NZPD (HR), 125 (1903): 693.

117 NZPD (HR), 126, (1903): 71.

118 NZPD: 71.

${ }^{119}$ NZPD: 72.

${ }^{120}$ NZPD: 71 per Walter C. Buchanan (Wairarapa).

${ }^{121}$ NZPD: 72, per James Bennett (Tuapeka).

122 NZPD: 72.

${ }^{123}$ NZPD: $393-4$.

${ }^{124}$ Although outside the scope of this paper, this story is interesting in itself.

${ }^{125} \mathrm{~J}$. Drummond, Our Feathered Immigrants; Evidence for and against Introduced Birds in New Zealand (Wellington: Government Printer, 1907): 1.

${ }^{126}$ Approximately 100 years after Resolution Island was abandoned as an off-shore reserve on its invasion by stoats, the Department of Conservation is taking steps towards its re-establishment.

${ }^{127}$ The submissions received on a Department of Conservation report, 'What Can we do About Ferrets?' (Wellington: Department of Conservation, 1999) resulted in a change to the Biosecurity Act whereby the ferret - the only domesticated member of the family - became classified as an unwanted organism, unable to be bred or sold.

${ }^{128}$ Potts had floated the idea in 1872 (T.H. Potts, 'Help Save our Birds', Nature 2 May, (1872): 5-6), and in 1877 Buller had concluded that 'expiring races of animals and plants linger longest and find their last refuge on sea-girt islands of limited extent' (W.L.A. Buller, 'On the Ornithology of New Zealand', a paper read before the Wellington Philosophical Society, 22 September 1877, Transactions and Proceedings of the New Zealand Institute $10(1877): 211)$. However, it was not until 1892 that any moves in that direction were made (with Governor Lord Onslow commissioning Buller in 1891 to compose his Memorandum that resulted in the establishment of such island sanctuaries as Little Barrier Island and Resolution Island).

${ }^{129}$ G. M. Thomson, 'Plant Acclimatization in New Zealand'. Transactions and Proceedings of the New Zealand Institute 33 (1900): 313, 321.

${ }^{130} \mathrm{P}$. Star, 'Native Bird Protection, National Identity and the Rise of Preservation in New Zealand to 1914', New Zealand Journal of History 36(2) (2002): 123, 127.

${ }^{131}$ Rev. P. Walsh, 'On the Future of the New Zealand Bush', Transactions and Proceedings of the New Zealand Institute 31 (1896): 490, 493.

${ }^{132}$ T.H. Potts, 'On Recent Changes in the Fauna of New Zealand', a paper read before the Philosophical Institute of Canterbury, 12 December, reprinted in Out in the Open: a Budget of Scraps of Natural History, gathered in New Zealand (Christchurch: Lyttelton Times, 1882): 221, 223.

${ }^{133}$ This list included W.T.L. Travers, botanist and member of the Linnean Society; T. Kirk, appointed Chief Conservator of Forests in 1885: T.F. Cheeseman, appointed Secretary of the Auckland Institute and Curator of the Auckland Museum in 1874; and J. Buchanan. long-time contributor to the TNZI in the area of botany.

${ }^{134}$ H. Guthrie Smith, Tutira: The Story of a New Zealand Sheep Station, $4^{\text {th }}$ ed. (Wellington: A.H. and A.W. Reed, 1969): 202-3. 


\section{PHILIPPA K. WELLS}

${ }^{135}$ This has been identified by various authors - for example see P. Star and L. Lochhead, 'Children of the Burnt Bush, New Zealanders and the Indigenous Remnant, 1880-1930 Water' in Environmental Histories of New Zealand, ed. E. Pawson and T. Brooking (Melbourne: OUP, 2002): 119, 122 and 131-2, P. Gibbon, “'Going Native”: a Case Study of Cultural Appropriation in a Settler Society, with Particular Reference to the Activities of Johannes Anderson in New Zealand during the First Half of the Twentieth Century' (Unpublished PhD Thesis, University of Waikato, 1992): 31 and Galbreath: 193.

${ }^{136}$ Otago Witness, 'Our Native Birds', Otago Witness 26 April (1894): 5.

137 'Disgusted', Letter to the Editor, Otago Daily Times 18 April (1900): 6.

${ }^{138} \mathrm{Sir}$ J. Hector, Address to Meeting of the Wellington Acclimatization Society, as reported in Otago Daily Times, 19 May 1897: 2. 